\title{
Når er reisetid arbeidstid?
}

Førsteamanuensis ph.d. Marianne Jenum Hotvedt

\section{$1 \quad$ Høyesteretts dom i HR-2018-1036-A Reisetid}

Høyesterett avsa 4. juni 2018 en dom - HR-2018-1036-A Reisetid - som gjaldt spørsmålet om når reisetid som faller utenfor alminnelig arbeidstid, skal regnes som arbeidstid. Dommen har skapt debatt, og forståelsen av den er påfallende sprikende. ${ }^{1}$ Enkelte mener dommen avklarer at alle reiser til arbeid andre steder enn det faste arbeidsstedet nå skal regnes som arbeidstid. ${ }^{2}$ Andre hevder at dommen kun avklarer et nokså særegent saksforhold, og flere legger til grunn at dommen ikke endrer det tradisjonelle utgangspunktet i norsk rett, om at reiser utenfor alminnelig arbeidstiden normalt ikke er arbeidstid. ${ }^{3}$

Behovet for en avklarende analyse er altså påtrengende, og denne artikkelen er et fors $\emptyset \mathrm{k}$ på det. Jeg drøfter hvilken rettsavklaring - og eventuelt rettsutvikling - dommen innebærer, med sikte på å klarlegge retningslinjer for vurderingen av om reisetid skal regnes som arbeidstid.

Saken gjaldt en politimann, og den omtvistede reisetiden knyttet seg til tre pålagte oppdrag der oppmøtestedet var et annet enn det faste tjenestestedet, og reisetiden lå utenfor alminnelig arbeidstid. To av oppdragene (et eskorteoppdrag og en narkotikaaksjon) var lagt i tilknytning til alminnelig arbeidstid, mens det tredje oppdraget (også et eskorteoppdrag) var lagt på en fridag. Siden arbeidsgiver hadde akseptert visse deler av reisene som arbeidstid, gjaldt tvisten den resterende reisetiden. ${ }^{4}$ På reisene dro politimannen innom lensmannskontoret, pakket tjenestebil med våpen og utstyr og kjørte den så til oppmøtestedet. Han bar både arbeidsgivers og egen mobiltelefon, og bilen var overvåket med GPS fra Operasjonssentralen.

De sprikende synene fremgår av titlene på flere innlegg i debatten: Merete Furesund og Tore Lerheim, «Reisetid er arbeidstid», Dagens Naringsliv 7. juni 2018, Hans Jørgen Bender, [sic.] «Skal arbeidstid regnes som reisetid?», Rett24.no 9. juni 2018, Agathe Løwenborg og Norah Rahimi, «Reisetid er ikke alltid arbeidstid», Dagens Naringsliv 14. juni 2018, Margrethe Meder, «Reisetid er ikke uten videre arbeidstid», Dagens Naringsliv 17. juni 2018 og Martin Jetlund og Marie Berggren Hagberg, «Kommentar til Høyesteretts dom om arbeidstid 4 juni 'Reisetidssaken'», Juridika.no 3. juli 2018. Se dessuten Thomas Keiserud og Camilla Selman, «Lønn for reise til og fra oppmøtested?», Dagens Naringsliv, 11. desember 2017, som er skrevet før Høyesteretts dom.

Furesund/Lerheim 2018 slår fast at «Høyesterett har ... avklart at reisetid i forbindelse med arbeid andre steder enn på fast arbeidssted, og som finner sted utenfor alminnelig arbeidstid, skal anses som arbeidstid».

Løwenborg/Rahimi 2018 betegner synet i Furesund/Lerheim 2018 som «forenklet og unyansert», understreker hvor «sammensatt og konkret» vurderingstemaet er, og hevder at EFTA-domstolen bygget på samme tolkning av arbeidstidsbegrepet som Høyesterett tidligere har gjort. Meder 2018 mener at «pålagt oppmøtested et annet sted enn fast arbeidssted ikke i seg selv betyr at reisetiden er arbeidstid», og hevder at begrunnelsen i dommen «tvert om» viser til «forhold som kun unntaksvis er aktuelle for andre arbeidstagere». Jetlund/Hagberg 2018 hevder at dommen «ikke representerer noen klar endring i dagens hovedregel, som er at reiser utenfor den alminnelige reisetiden [sic: skal nok være 'arbeidstiden'] ikke er arbeidstid». Både Keiserud/Selman 2017 og Bender 2018 sier seg uenig med Furesund/Lerheim 2018. delvis akseptert som arbeidstid, primært fordi det var utført arbeidsoppgaver underveis. 
Saken reiste to hovedspørsmål. Det første var om reisetiden skulle anses som arbeidstid etter arbeidsmiljøloven ${ }^{5}$ kapittel 10. Spørsmålet gjaldt altså tolkningen av lovgivningens arbeidstidsbegrep og det grunnleggende skillet mellom arbeidstid og arbeidsfri/hviletid. Tolkningen hadde en EØS-rettslig side, idet aml. kap. 10 gjennomfører EUs arbeidstidsdirektiv. ${ }^{6}$ Høyesterett hadde innhentet EFTA-domstolens uttalelse om tolkningen av direktivets arbeidstidsbegrep, og EFTA-domstolen la klart til grunn at den omtvistede reisetiden var arbeidstid etter direktivet. ${ }^{7}$ Høyesterett konkluderte i tråd med uttalelsen med at reisetiden var arbeidstid etter de bestemmelsene i arbeidsmiljøloven som gjennomfører direktivet.

Det andre spørsmålet var hvilken godtgjørelse reisetiden ga politimannen krav på. Det berodde på en tolkning av de tariffavtalene som gjaldt mellom partene. Verken direktivet eller arbeidsmiljøloven regulerer godtgjørelse. ${ }^{8}$ Godtgjørelsen var imidlertid regulert i Hovedtariffavtalen i staten samt i en særavtale for politi- og lensmannsetaten. ${ }^{9}$ Høyesterett tolket tariffavtalene på selvstendig grunnlag, og fant at reguleringen ikke bygget på lovens todeling mellom arbeidstid og arbeidsfri/hviletid. Godtgjørelsen var differensiert og sondret mellom «ren» reisetid og arbeidstid, og dette arbeidstidsbegrepet ble forstått som tid i aktivt arbeid. Mens aktivt arbeid ga rett til overtidsgodtgjørelse, ga reisetid «bare» rett til time-fortime kompensasjon. Retten delte seg imidlertid i rettsanvendelsen. Flertallet (fire dommere) mente de omtvistede reisene ikke utgjorde aktivt arbeid. ${ }^{10}$ Mindretallet (én dommer) vurderte all reisetiden som aktivt arbeid som ga krav på overtidsgodtgjørelse.

Vurdering av godtgjørelsesspørsmålet har begrenset prinsipiell interesse. Arbeidsretten har eksklusiv kompetanse til å avgjøre tvister mellom tariffavtalens parter om tolkning av tariffavtalen eller om krav som bygger på den, jf. arbeidstvistloven ${ }^{11} \S 33$ (2), jf. § 1 bokstav i. Høyesteretts tariffavtaletolkning kun derfor er prejudisiell. ${ }^{12}$ Lovtolkningen kan derimot ha

Lov 17. juni 2005 nr. 62 om arbeidsmiljø, arbeidstid og stillingsvern mv. (arbeidsmiljøloven, aml.).

Direktiv 2003/88/EF av 4. november 2003 om visse aspekter ved organisering av arbeidstiden (arbeidstidsdirektivet). Direktivet erstatter direktiv 93/104/EF og 2000/34/EF. Arbeidstidsdefinisjonen har ligget fast. Det opprinnelige direktivet ble besluttet innlemmet i EØS-avtalen ved EØS-komiteens vedtak 28. juni 1996 og gjennomført i lov 4. februar $1977 \mathrm{nr} .4$ om arbeidervern og arbeidsmiljø (aml. 1977) ved lovendring 30. april $1998 \mathrm{nr} .24$. EFTA-domstolens uttalelse i sak E-19/16 Thue.

8 Et unntak er at aml. § 10-6 (11) krever overtidstillegg på minst 40 prosent, men bestemmelsen kan fravikes ved tariffavtale, jf. aml. § 10-12 (4).

Se fellesbestemmelsene i Hovedtariffavtalen for Staten for perioden 1. mai 2012 til 30. april 2014 (HTA 2012) og særavtale om «Arbeidstidsbestemmelser for politi- og lensmannsetaten» (ATB 2013) for perioden 1. april 2013 til 31. desember 2015. Politimannen i saken var bundet som medlem i Politiets Fellesforbund. Det tredje oppdraget ga likevel rett til overtidsgodtgjørelse etter en særskilt hjemmel i ATB $2013 \S 15 \mathrm{nr}$. 7 pkt. 2 idet beordringen gjaldt en fridag.

12 Som sådan har tarifftolkningen nokså bred aktualitet. Skillet mellom «ren» reisetid og aktivt arbeid fulgte av både HTA 2012 og ATB 2013, og det synes ikke å gjort være materielle endringer i tariffavtalene som har avløst disse. Tolkningen har derfor - enn så lenge - relevans for alle statsansatte. 
vidtrekkende praktisk og prinsipiell betydning, og det er i hovedsak den debatten har kretset rundt. Jeg konsentrerer meg derfor om lovtolkningsspørsmålet.

Det er imidlertid grunn til å merke seg at Høyesterett, ved vurderingen av om det forelå rettslig interesse, presiserte lovtolkningsspørsmålet og tydelig skilte det fra tariffavtaletolkningen. Kravet om at reisetiden «anses som arbeidstid»var ifølge staten for upresist til å være et rettskrav. Staten mente det heller ikke var et reelt behov for en avgjørelse, siden man etter EFTA-domstolens uttalelse hadde akseptert politimannens reiser som arbeidstid etter direktivet og de parallelle lovbestemmelsene. Høyesterett fremmet saken til behandling, men med en viktig presisering. Kravet ble tolket slik at det kun gjaldt «rekkevidden av vernebestemmelsene i arbeidsmiljøloven kapittel 10» (avsnitt 40). Førstvoterende understreket samtidig at en avgjørelse i politimannens favør «ikke er avgjørende for hva som skal anses som arbeidstid i andre sammenhenger, verken i tariffavtaler, i andre deler av arbeidsmiljøloven eller i lovgivningen for øvrig» (avsnitt 44). Dette la fundamentet for den ulike tolkningen av lovens og tariffavtalenes arbeidstidsbegreper.

Tolkningen av lovens arbeidstidsbegrep i Reisetid er preget av to typer av spenninger. For det første måtte tradisjonell norsk forståelse konfronteres med direktivets begrepsinnhold. EFTA-domstolen var involvert fordi det kunne være et spenningsforhold. For det andre trakk Høyesterett opp begrepets grenser ved hjelp av både generelle og temmelig konkrete vurderinger. Høyesterett gjenga premisser fra EFTA-domstolen som er generelle i formen, men påpekte samtidig de konkrete og spesielle forholdene i saken. ${ }^{13}$ Høyesterett tok ikke stilling til forholdet mellom de generelle og konkrete vurderingene, og de står dermed i et uavklart spenningsforhold. Særlig det siste skaper usikkerhet om avgjørelsens rekkevidde og betydning. Uenigheten om dommen synes nettopp å ha sitt utspring i disse spenningene; man fokuserer på ulike begrepstradisjoner og enten på de generelle eller de konkrete delene av argumentasjonen.

I det følgende vil jeg derfor først diskutere forholdet mellom forståelsen av arbeidstidsbegrepet etter norsk tradisjon og etter EU/EØS-retten, med sikte på å tydeliggjøre spenningsforholdet (punkt 2). Så drøfter jeg hvordan Høyesterett i Reisetid forholdt seg til EFTA-domstolens uttalelse, og konkluderer med at Høyesterett la EFTA-domstolens tolkning av arbeidstidsbegrepet til grunn (punkt 3). Deretter diskuterer jeg hva denne tolkningen går ut på, særlig med sikte på å klarlegge om den gir grunnlag for retningslinjer med betydning ut over de konkrete saksforholdene (punkt 4). Så oppsummerer jeg retningslinjene og vurderer om de representerer en utvikling av norsk tradisjon (punkt 5). Jeg avslutter med noen bemerkninger om de utfordringene som nå knytter seg til arbeidstidsbegrepet (punkt 6). 


\section{$2 \quad$ Utgangspunktet for tolkningen: En spenning mellom tradisjonell norsk og EU/EØS-rettslig forståelse av arbeidstidsbegrepet?}

Siden aml. kap. 10 gjennomfører arbeidstidsdirektivet, måtte Høyesterett anvende både norske og EU/EØS-rettslige kilder. Et viktig spørsmål er om utgangspunktet for tolkningen av arbeidsbegrepet er den samme etter de to rettstradisjonene.

Arbeidstidsreglene i loven og direktivet er tilsynelatende bygget over samme lest og hviler på de samme internasjonale prinsippene. ${ }^{14}$ Begrepet 'arbeidstid' er definert som en motsetning til 'arbeidsfri' eller 'hviletid'. ${ }^{15}$ Definisjonene refererer til det å stå til arbeidsgivers disposisjon, men ordlyden samsvarer ikke fullt ut. Etter aml. § 10-1 (1) er arbeidstid «den tid arbeidstaker står til disposisjon for arbeidsgiver», mens direktivet art. $2 \mathrm{nr}$. 1 definerer det som «alle perioder der arbeidstakeren er i arbeid, står til arbeidsgiverens disposisjon og utfører sine arbeidsoppgaver eller plikter, i samsvar med nasjonal lovgivning og/eller praksis». ${ }^{16}$ Endring i arbeidstidsdefinisjonen ble ikke ansett nødvendig ved gjennomføringen av direktivet. ${ }^{17}$ Det er samtidig klarlagt at direktivets begrep er autonomt og ikke kan fravikes, tross ordlydens henvisning til nasjonal rett. ${ }^{18}$ Hvorvidt direktivets begrep legger press på arbeidsmiljølovens, beror derfor på om begrepene tolkes og avgrenses på tilsvarende måte i de to tradisjonene.

Om den generelle tolkningen har Høyesterett uttalt at «til disposisjon» etter aml. § 10 (1) forutsetter at «arbeidstaker står til disposisjon for arbeidsgiver for å utføre arbeidsoppgaver i henhold til arbeidsavtalen». ${ }^{19}$ Tilsvarende er lagt til grunn forarbeidene. ${ }^{20}$ EU-domstolen bygger imidlertid på at begrepet kjennetegnes ved tre elementer: For å være arbeidstid må arbeidstakeren (1) utføre sine arbeidsoppgaver eller plikter innenfor rammen av sitt arbeidsforhold; (2) stå til arbeidsgiverens disposisjon; og (3) også arbeide. Domstolen understreker regelmessig at begrepet må tolkes i lys av formålet om å verne arbeidstakernes

14 Norske regler bygger på prinsippene om arbeidstid i ILO, se særlig ILO konvensjon nr. 14 om ukentlig hvile i industrielle foretak (1921, ratifisert av Norge 7. juli 1937), ILO-konvensjon nr. 30 om arbeidstid for handels- og kontorvirksomheter (1930, ratifisert av Norge 29. juni 1953) og ILO-konvensjon nr. 47 om 40 timers uke (1935, ratifisert av Norge 13. mars 1979). Også arbeidstidsdirektivet er utformet med utgangspunkt i prinsippene, se fortalen punkt 6.

Lovens motsats er «arbeidsfri» og direktivets er «hviletid». I aml. 1977 § 46 var motsatsen «fritid». Definisjonene i loven av 2005 skulle videreføre gjeldende rett og også gjennomføre direktivets todeling. Det tilsier at det ikke er noen realitetsforskjell mellom «fritid»og «arbeidsfri».

Også i ILO-konvensjon nr. 30 art. 2 er arbeidstid definert i motsetning til hviletid: «the term hours of work means the time during which the persons employed are at the disposal of the employer; it does not include rest periods during which the persons employed are not at the disposal of the employer» (uthevet $\mathrm{i}$ originalen).

Ot.prp. nr. 67 (1996-1997) s. 27.

Se bla. sak C-151/02 Jager, EU:C:2003:437, avsnitt 59 og sak E-5/15 Matja Kumba avsnitt 38. Unntaksadgangen i direktivet åpner ikke for å fravike arbeidstidsbegrepet, se sak C-258/10 Grigore, EU:C:2011:122, avsnitt 45. 
sikkerhet og helse. ${ }^{21}$ EU-domstolen har ikke tatt klart stilling til om elementene utgjør kumulative eller kumulative vilkår. ${ }^{22}$ Rettspraksis gir st $\varnothing t t e$ for at de er kumulative, men særlig det tredje elementet tolkes så vidt at det får mindre selvstendig betydning. ${ }^{23}$

Den nærmere avgrensningen mot arbeidsfri/hviletid er ansett å bero på en konkret vurdering både etter norsk og EU-rettslig tradisjon. EU-domstolens grensedragning har imidlertid vært strukturert opp mot de tre begrepselementene.

Når det gjelder klassifiseringen av reisetid, heter det i forarbeidene til arbeidsmiljøloven:
«Reise til og fra arbeidet vil som i dag falle utenfor definisjonen av arbeidstid. Dersom arbeidstakeren i løpet av arbeidsdagen reiser til arbeidssteder utenfor virksomheten og vender tilbake igjen, vil reisetiden normalt regnes som arbeidstid. Annen reisetid i forbindelse med arbeid lengre unna arbeidsstedet hvor for eksempel overnatting er nødvendig vil ikke være arbeidstid, med mindre arbeidstakeren blir pålagt plikter slik at vedkommende likevel må sies å stå til arbeidsgivers disposisjon.» 24

Her er det slått fast - uten forbehold - at reiser til og fra arbeidsstedet («arbeidet») ikke er arbeidstid. Videre er det lagt til grunn at reiser innenfor alminnelig arbeidstid («i løpet av arbeidsdagen»), normalt regnes som arbeidstid. Forutsetningen synes å være at det er tale om kortere reiser ut fra det faste arbeidsstedet («virksomheten»). I teorien er dette forstått slik at reisetiden vil være arbeidstid dersom man møter opp på arbeidsstedet, reiser ut og returnerer innenfor en normal arbeidsdag. ${ }^{25}$ «Annen reisetid» enn dette er derimot ikke ansett som arbeidstid, med mindre man er pålagt plikter slik at man «likevel» står til arbeidsgivers disposisjon. Forutsetningen her er imidlertid at det dreier seg om «arbeid lengre unna arbeidsstedet».

Disse uttalelsene tar ikke klart stilling til alle typer reiser. Men sett i sammenheng er de tatt til inntekt for et alminnelig utgangspunkt om at reise utenfor alminnelig arbeidstid, til og fra det stedet arbeidet skal utføres, ikke er arbeidstid, enten det er tale om den vanlige reisen «til og fra arbeidet», eller reiser til «arbeid lengre unna arbeidsstedet». ${ }^{26}$ Et motsatt utgangspunkt er bare ansett å gjelde for reiser i løpet av arbeidsdagen, med arbeidsstedet som utgangs- og returpunkt.

Reisetid er ikke vurdert på samme måte etter direktivet. I Tyco regnet EU-domstolen tid brukt på reise mellom bopel og dagens første og siste kunde som arbeidstid. Saken var imidlertid litt spesiell, blant annet fordi arbeidstakerne $i k k e$ hadde et fast oppmøtested. ${ }^{27}$ Kommisjonen har avgitt en meddelelse om tolkningen av direktivet som også berører andre

Se bla. Jager avsnitt 45 flg. og sak C-266/14 Tyco, EU:C:2015:578, avsnitt 23.

Catherine Barnard, EU Employment Law, 4. utgave, Oxford 2012 s. 547.

Ibid., med henvisning blant annet til Jaeger og dom 3. oktober 2000, sak C 303-/98 Simap, EU:C:2000:528. Ot.prp. nr. 49 (2004-2005) s. 315.

Jan Fougner, Lars Holo, Tron Løkken Sundet og Tarjei Thorkildsen, Arbeidsmiljøloven. Lovkommentar, 3. utgave, Oslo 2018 s. 402.

Se slik også Reisetid avsnitt 52.

Dommen er nærmere diskutert i punkt 4, særlig 4.3. 
varianter av reisetid. ${ }^{28}$ Om reiser i løpet av arbeidsdagen heter det at disse «kunne betraktes som arbeidstid», dersom betingelser knyttet til de tre begrepselementene er oppfylt. ${ }^{29}$ Når det gjelder «vanlige» reiser til og fra arbeidet, er det trukket et skille ut fra om arbeidstakeren har et fast arbeidssted eller ikke. Der arbeidstaker ikke har et fast arbeidssted, følger det av Tyco at reisetiden gjerne kan være arbeidstid, og avgjørelsen gir nærmere retningslinjer for når. Der arbeidstakeren har et fast arbeidssted, er det derimot «ikke noget, der tyder på» at reisetiden er arbeidstid etter direktivet. ${ }^{30}$ Kommisjonen har ikke uttalt seg særskilt om reiser til annet oppmøtested enn det faste, utenfor alminnelig arbeidstid.

Retningslinjene for klassifisering av reisetid etter direktivet er følgelig verken like klare eller sortert på samme måte som i norsk rett: Retningslinjene er tett knyttet til tre begrepselementer, de rommer flere forbehold, og de nyanserer til dels ut fra andre forhold.

Tross fellestrekkene i den grunnleggende begrepsforståelsen skaper dette et spenningsforhold mellom tradisjonell norsk og EU/EØS-rettslig forståelse av arbeidstidsbegrepet.

\section{Forholdet mellom Høyesteretts og EFTA-domstolens tolkninger}

Spenningen i begrepstradisjon gjør det særlig viktig å klargjøre hvordan Høyesterett forholdt seg til EFTA-domstolens tolkning. Bygget Reisetid på EFTA-domstolens tolkning av arbeidstidsbegrepet? La Høyesterett eventuelt selvstendige føringer for tolkningen, basert på norsk tradisjon? Siden dette er så sentralt for forståelsen av dommen, går jeg grundig gjennom Høyesteretts resonnement.

Førstvoterende tok utgangspunkt i rent nasjonale kilder. Hun refererte definisjonen i aml. § 10-1 og uttalelser fra forarbeidene, og hun trakk frem Rt. 2001 s. 418 Kårstø (avsnitt 46-49). Hun mente at Høyesterett der hadde stilt «strenge krav til at reisetid skal anses som arbeidstid», men la den til side fordi den gjaldt reisetiden til og fra det faste arbeidsstedet. ${ }^{31}$

Så gikk hun nærmere inn på forarbeidsuttalelsene. Hun fremholdt at saken gjaldt «reisetid utenom arbeidstiden», som i utgangspunktet ikke er arbeidstid «med mindre arbeidstakeren er pålagt å utføre arbeidsoppgaver i henhold til arbeidsavtalen og derfor må sies å stå til arbeidsgivers disposisjon» (avsnitt 52). Så langt bygget tolkningen altså på tradisjonelle utgangspunkter i norsk rett.

Se Kommisjonens tolkningsmeddelse om arbeidstidsd irektivet 24. mai 2017, EFT 2017/C 165/01 (tolkningsmeddelelsen).

Ifølge tolkningsmeddelelsen s. 19 må reisen (1) utgjøre en nødvendig forutsetning for at arbeidstakeren kan utføre sine plikter og derfor betraktes som perioder der man utfører sine arbeidsoppgaver, (2) arbeidstakeren må stå til arbeidsgiverens disposisjon, altså etterkomme arbeidsgivers anvisninger og ikke stå fritt til å bruke tiden i sin egen interesse og (3) reisen må være en «uadskillelig del» av arbeidstakerens arbeid, og arbeidsstedet derfor ikkje kunne innskrenkes til det fysiske arbeidsstedet hos kundene.

Se nærmere om Kårstø i punkt 5. 
Den nærmere lovtolkningen bygget imidlertid på rent EØS-rettslig kilder. Etter presentasjon av direktivets definisjon, gikk førstvoterende over til uttalelsen fra EFTAdomstolen (avsnitt 53 flg.). EFTA-domstolens tolkning ble verken diskutert eller utlagt på selvstendig vis. Førstvoterende nøyde seg med å referere deler av vurderingene (avsnitt 5760), bare avbrutt av en bemerkning om at EFTA-domstolen dermed trakk frem «både generelle og individuelle karakteristika ved de aktuelle reisene» (avsnitt 59). Førstvoterende kommenterte heller ikke rekkevidden av uttalelsen, på tross av partenes uenighet om dette. Men hun slo klart fast at uttalelsen var «klar» om de reisene saken gjaldt (avsnitt 62).

Tolkningsuttalelsens betydning for fastleggelse av EØS-retten ble uttrykkelig vurdert. Selv om nasjonale domstoler må ta «selvstendig stilling» til forståelsen og anvendelsen av EØSrett, skal EFTA-domstolens forståelse «likevel normalt» følges av hensyn til rettsenhet, og fravik er bare aktuelt ved «særlige grunner» (avsnitt 63). Slike «særlige grunner» forelå ikke i dette tilfellet (avsnitt 64).

Som et siste ledd i vurderingen ble forholdet mellom direktivets og arbeidsmiljølovens arbeidstidsbegreper kort kommentert. Siden lovgiver har forutsatt at de parallelle vernebestemmelsene i loven er i samsvar med direktivet, fulgte det av presumsjonsprinsippet at disse regler «tolkes på samme måte» som direktivets begrep (avsnitt 65). Konklusjonen måtte da bli at den omtvistede reisetiden var arbeidstid «etter de bestemmelsene $\mathrm{i}$ arbeidsmiljøloven kapittel 10 som implementerer direktivet» (avsnitt 66).

Det kan etter dette ikke herske tvil om at EFTA-domstolens uttalelse var styrende for tolkning og rettsanvendelse. Tradisjonell norsk forståelse fikk fungere som et utgangspunkt, men den nærmere lovtolkningen dreide seg om innholdet i direktivets arbeidstidsbegrep. Her støttet Høyesterett seg nesten utelukkende på EFTA-domstolens tolkning, og slo klart fast at arbeidsmiljølovens bestemmelser måtte forstås likt. EFTA-domstolens forståelse av direktivets arbeidstidsbegrep ble dermed lagt til grunn ved tolkningen og anvendelsen av de parallelle bestemmelsene i arbeidsmiljøloven.

Etter min vurdering gir Reisetid ikke grunnlag for forbehold knyttet til EFTA-domstolens uttalelse, verken når det gjelder innholdet i tolkningen eller rekkevidden for andre saksforhold.

Høyesteretts gjengivelse av uttalelsen var riktignok forenklet og utelot enkelte premisser. Men så lenge resonnementet og vurderingene verken ble forsøkt tolket eller kritisert, lar det seg vanskelig utlede noen forbehold knyttet til tolkningens innhold.

At Høyesterett unnlot å ta stilling til uttalelsens «rekkevidde», og bemerkningen om at den bygget på både generelle og individuelle karakteristika, kan neppe forstås som et forbehold. Det synes heller å speile en usikkerhet om hva som kan utledes av uttalelsen; om EFTAdomstolens tolkning kun gir veiledning i tilsvarende saksforhold eller gir retningslinjer med mer generell rekkevidde. Når Høyesterett ikke selv tok stilling til denne usikkerheten, blir konsekvensen at andre rettsanvendere selv må søke svar i EFTA-domstolens uttalelse. 
Det Høyesterett var tydelig på, var rekkevidden hva gjelder hvilke regler tolkningen har betydning for. Høyesterett tok kun stilling til arbeidstidsbegrepet i visse regler - «de vernebestemmelsene i arbeidsmiljøloven kapittel 10 som gjennomfører arbeidstidsdirektivets krav». Men det er noe helt annet enn et forbehold knyttet til tolkningens innhold og betydning for andre saksforhold.

Høyesteretts resonnement i Reisetid innebærer derfor etter mitt syn at EFTA-domstolens tolkning av arbeidstidsbegrepet, er lagt til grunn. Spørsmålet om hva tolkningen går ut på - og hvorvidt den gir grunnlag for mer generelle retningslinjer - drøftes derfor med utgangspunkt i EFTA-domstolens uttalelse.

\section{$4 \quad$ EFTA-domstolens tolkning av arbeidstidsbegrepet}

\subsection{Tolkningsspørsmålene og domstolens tilnærming}

I uttalelsen tok EFTA-domstolen stilling til følgende tre spørsmål:

I. Er den tiden som medgår til en reise pålagt av arbeidsgiver, til og/eller fra et annet oppmøtested enn arbeidstakerens faste eller sedvanlige oppmøtested, når reisen skjer utenfor alminnelig arbeidstid, å anse som arbeidstid etter artikkel 2 i direktiv 2003/88/EF?

II. I den grad en reise som beskrevet i spørsmål I ikke i seg selv er tilstrekkelig til klassifisering som arbeidstid, hva er det rettslige vurderingstemaet og de relevante momentene for vurderingen av om reisetiden likevel blir arbeidstid? Det bes herunder omtalt om det skal foretas en intensivitetsvurdering av innslaget av arbeid på reise.

III. Har det betydning for vurderingene under spørsmål I og II hvor ofte arbeidsgiver fastsetter et annet oppmøtested enn det som er arbeidstakerens faste eller sedvanlige arbeidssted?

Domstolen vurderte det første og tredje spørsmålet i sammenheng, og men fant etter det ikke grunn til å vurdere det andre spørsmålet nærmere. Tolkningsspørsmålene ble besvart slik:

1. Den nødvendige tid som medgår til reise utenfor alminnelig arbeidstid for en arbeidstaker som den ankende part til og/eller fra et annet sted enn hans faste eller sedvanlige oppmøtested for å utføre sine arbeidsoppgaver eller plikter på dette andre sted som angitt av arbeidsgiver, utgjør «arbeidstid» etter artikkel 2 i direktiv 2003/88/EF.

2. Det kreves ingen vurdering av intensitet av den mengde arbeid som utføres på reisen.

3. Hvor ofte slike reiser finner sted, er uvesentlig med mindre virkningen er at arbeidstakerens arbeidssted flyttes til et nytt fast eller sedvanlig oppmøtested.

Tilnærming til tolkningen var helt konvensjonell. Domstolen fremhevet direktivets formål om beskyttelse av sikkerhet og helse (avsnitt 63), stadfestet at arbeidstidsbegrepet tolkes autonomt (avsnitt 67) og at begrepene 'arbeidstid' og 'hviletid' er gjensidig utelukkende (avsnitt 68). Det ble avvist allerede innledningsvis at bare aktivt arbeid kan være arbeidstid, idet et slikt krav ikke har hjemmel i direktivet (ibid.). 
Utgangspunktet for avgrensingen av begrepet var også velkjent. Domstolen poengterte at skillet kan være marginalt, og at avgrensningen beror på en konkret vurdering i den enkelte sak, der flere faktorer tas i betraktning (ibid.). Utgangspunktet ble følgelig angitt helt nøytralt. De omtvistede tidsrommene var allerede beskrevet (avsnitt 65), og det var slått fast at politimannen hadde et fast oppmøtested (avsnitt 67). Likevel formulerte domstolen ikke noe utgangspunkt om, eller noen presumsjon for, at reisetiden var eller ikke var arbeidstid.

Domstolens nærmere vurdering var knyttet opp til de tre begrepselementene, helt i tråd med praksis. Vurderingene blir diskutert straks nedenfor (punkt 4.2). De bygget gjennomgående på EU-domstolens premisser i Tyco. Som antydet ovenfor lå denne saken annerledes an.

Bakgrunnen for tvisten i Tyco var en endring, som førte til at arbeidstakere som hadde hatt et fast oppmøtested, ikke lenger hadde det. Om EFTA-domstolen bruk av premisser fra Tyco er et brudd med EU-domstolens praksis, blir drøftet etterpå (punkt 4.3).

Tyco drev installering og vedlikehold av sikkerhetssystemer, og teknikere utførte slikt arbeid ute hos kunder. De var først tilknyttet regionkontorer, og arbeidstiden ble beregnet fra oppmøte på regionkontoret. Tvisten oppstod da Tyco la ned regionkontorene og knyttet alle medarbeidere til hovedkontoret. Arbeidstiden ble da regnet fra oppmøte hos dagens første kunde til avreise fra dagens siste kunde. Teknikerne disponerte firmabil og en mobiltelefon for å kommunisere med hovedkontoret, med en applikasjon som viste neste dags kjøreplan. Én eller flere ganger i uken måtte de innom en logistikksentral for å hente materialer, reservedeler mv. Etter en vurdering av de tre begrepselementene konkluderte EU-domstolen med at reisetiden mellom bopel og dagens første og siste kunde var arbeidstid etter direktivet.

\subsection{Vurderingen av de tre elementene $i$ arbeidstidsbegrepet}

Spørsmålet i det følgende er hva som kan utledes av EFTA-domstolens vurderinger av de tre begrepselementene, særlig om domstolen legger premisser med betydning ut over de konkrete (og spesielle) saksforholdene.

Det første elementet er at arbeidstakeren må utføre sine arbeidsoppgaver eller plikter innenfor rammen av sitt arbeidsforhold. EFTA-domstolen la til grunn at når en arbeidstaker gjennomfører en reise for å utføre oppgaver pålagt av arbeidsgiver på et annet sted enn sitt faste eller sedvanlige oppmøtested, er reisen «en nødvendig og vesentlig forutsetning for at arbeidstakeren skal kunne ivareta sine arbeidsoppgaver på en pliktoppfyllende måte» (avsnitt 70). Dette bygget på et premiss fra Tyco. ${ }^{32}$

EFTA-domstolens premiss er gitt i generell form, og det ble lagt til grunn uten å trekke inn de konkrete omstendighetene. Forholdene under reisene ble først vurdert i tilknytning til det andre elementet, se straks nedenfor. Begrunnelsen for å bygge på Tyco var klar og prinsipiell, premisset hadde overføringsverdi ut fra formåls- og systembetraktninger. ${ }^{33}$ Domstolen oppstilte dessuten helt generelle retningslinjer for beregningen av reisetiden til et annet

Tyco avsnitt 32.

Se nærmere i punkt 4.2. 
oppmøtested: Reisen skal anses begynt og avsluttet enten på bopel eller på det vanlige oppmøtestedet. Valget skal bero på hva som er «mest rimelig», i lys av hvilket alternativ som gir kortest reisetid (avsnitt 72).

Dette tilsier at premisset har generell relevans ved vurderingen av om reisetid til annet oppmøtested enn et fast, er arbeidstid. Sett i sammenheng med Tyco gir rettspraksis tilsvarende føringer for arbeidstakere med og uten et fast oppmøtested. Det sentrale og avgjørende for om det første elementet i begrepet er tilstede, er om reisen er en «en nødvendig og vesentlig forutsetning» for å oppfylle arbeidsavtalen. Inntrykket er altså at domstolen oppstilte et utgangspunkt med nokså vid rekkevidde.

Premisset rommer imidlertid to viktige reservasjoner, som henger sammen. Det er forutsatt at arbeidsoppgaver på et annet oppmøtested var pålagt og at reisetiden er nфdvendig. ${ }^{34}$ Dersom oppgavene kan utføres på det faste arbeidsstedet, eventuelt på et sted med kortere reiseavstand, er reisen ikke en nødvendig forutsetning for å oppfylle arbeidsavtalen. Men så lenge reisen er nødvendig for å utføre pliktige oppgaver, det kan neppe kreves at arbeidsgiver gir et uttrykkelig pålegg om den aktuelle reisen. ${ }^{35}$

Arbeidstidsbegrepets andre element er at arbeidstakeren i løpet av denne tiden må stå til arbeidsgiverens disposisjon. Her nærmet EFTA-domstolen seg grensen mellom arbeidstid og hviletid skritt for skritt, på basis av Tyco og annen praksis.

Først ble kjennetegn for hvert av begrepene presisert. Kjennetegn ved 'arbeidstid' ble utlagt både positivt og negativt. Arbeidstakeren må «være i en situasjon der han er rettslig forpliktet til å følge sin arbeidsgivers instrukser og utføre sine arbeidsoppgaver for arbeidsgiveren» (avsnitt 73). Det ble ikke forklart nærmere hva dette innebærer. Det ble i stedet påpekt at intensiteten i arbeidet ikke er et kjennetegnende element (ibid.). Kjennetegn ved 'hviletid' ble utlagt positivt. Muligheten til å organisere sin tid «uten større begrensninger og til å beskjeftige seg med egne interesser» kan vise at tiden er hviletid (avsnitt 74). Det er sentralt om arbeidstakeren er pålagt å oppholde seg på arbeidsplassen, og domstolen utdypet: «Det er bare når arbeidstakerne kan forlate arbeidsmiljøet i hvileperiodene og fritt og uavbrutt beskjeftige seg med egne interesser, at hvileperiodene kan anses effektive og ikke utgjøre 'arbeidstid'» (ibid.).

Domstolen presiserte altså først og fremst hva som ikke kreves for at tiden er arbeidstid, samt hva som positivt kjennetegner hviletid. Uttalelsene var samtidig ganske klare. Så langt var det derfor i første rekke hviletidsbegrepet som bidro til presisering. Presiseringene er helt generelle og ikke knyttet til de konkrete saksforholdene. Det indikerer at den konkrete avgrensningen av arbeidstidsbegrepet - både i saken og ellers - primært må trekkes fra motsatt hold, ved hjelp av kjennetegnene ved hviletid. Domstolen antydet med andre ord at

34 Thue avsnitt 85 (svaret pkt. 1) gjelder den «nødvendige tid som medgår til reise».

35 Saken gjaldt en «reise pålagt av arbeidsgiver», se Thue avsnitt 18 (spørsmål nr. 2), men domstolen fokuserte på at arbeidstakeren reiste til et annet sted for å utføre oppgaver der «som angitt av arbeidsgiver», se avsnitt 75. Se også avsnitt 80 og konklusjonen i avsnitt 85 (svaret pkt. 1). 
det sentrale vurderingstemaet ved den konkrete grensedragningen er om tiden er effektiv som hviletid.

Først etter dette gikk domstolen nærmere inn på forholdene i saken. Det bærende premisset er avsnitt 75, der domstolen foretok den konkret vurderingen og konkluderte med at arbeidstakeren stod til arbeidsgiverens disposisjon. ${ }^{36}$ Avsnittet lyder:

\begin{abstract}
«En arbeidstaker som er i en tilsvarende situasjon som den ankende part ved at han reiser til og/eller fra et annet sted enn sitt faste eller sedvanlige oppmøtested for å utføre sine arbeidsoppgaver eller plikter på dette andre sted som angitt av arbeidsgiver, kan ha en viss grad av fleksibilitet og valgfrihet med hensyn til transportmiddel og alternative reiseruter. Imidlertid er denne reisetid nødvendig, og i løpet av denne tid er arbeidstakeren forpliktet til å følge arbeidsgiverens instrukser, og arbeidsgiveren kan fritt avlyse, endre eller legge til oppdrag. Under den nødvendige reisetid, som normalt ikke kan forkortes, kan arbeidstakeren ikke fritt og uten avbrudd beskjeftige seg med egne interesser og står altså til arbeidsgivers disposisjon (jf. Tyco, som omtalt over, avsnitt 39).»
\end{abstract}

Selv om vurderingen var knyttet til de konkrete forholdene, gir den en viss generell veiledning. Domstolen vektla momenter som trakk i ulik retning. Muligheten for «fleksibilitet og valgfrihet» med hensyn til transportmiddel og reiserute ble holdt opp mot reisetidens nødvendighet, plikt til å følge arbeidsgivers instrukser og dennes mulighet til å endre oppdraget. Vektingen av momentene ble ikke kommentert. Slutningen var i stedet knyttet til kjennetegn ved hviletid, slik det ble presisert ovenfor. At arbeidstakeren stod «til arbeidsgivers disposisjon» ble fremstilt som en direkte konsekvens av at han ikke «fritt og uten avbrudd [kunne] beskjeftige seg med egne interesser», jf. «står altså til ... disposisjon» (kursivert her). At reisetiden var nødvendig ble imidlertid trukket inn, jf. «den nødvendige reisetid».

Dette legger etter min oppfatning flere generelle føringer for den konkrete vurderingen av om arbeidstaker står til arbeidsgivers disposisjon. Slutningen forsterker inntrykket av at det sentrale vurderingstemaet er om tiden er effektiv som hviletid. Det er videre naturlig å lese premisset som en bekreftelse av de to reservasjonene domstolen la inn ved vurderingen av det første elementet: Det var forutsatt at arbeid på oppmøtestedet pålagt (eller «angitt») av arbeidsgiver, og slutningen er knyttet til $n \varnothing d v e n d i g$ reisetid. For $\emptyset$ vrig indikerer uttalelsen en nokså høy terskel for å anse reisetid som effektiv hviletid. Dels er det nærliggende å forstå «fritt og uavbrutt» som et strengt krav, dels synes det forutsatt at «en viss fleksibilitet og valgfrihet» med hensyn til transportmiddel og rute ikke er tilstrekkelig til å anse reisen som hviletid.

Når vurderingen av de første to elementene sees i sammenheng, blir linjen i resonnementet klarere. Ved vurderingen av det første elementet oppstilte domstolen et rettslig utgangspunkt, og vurderingen av det andre viste hva som kreves for å fravike dette. Den konkrete

36 I de påfølgende avsnittene trakk domstolen slutninger fra dette (avsnitt 76), supplerte med utfyllende saksopplysninger (avsnitt 77) og kommenterte konsekvensene av sitt syn (avsnitt 78). 
vurderingen av det andre elementet fungerer dermed både som en nyansering og en bekreftelse av utgangspunktet.

At domstolen foretok en konkret vurdering, viser for det første at det utgangspunktet som var etablert, må nyanseres. Selv nødvendig reisetid til pålagt arbeid på annet oppmøtested er ikke automatisk arbeidstid. Hvis dette hadde vært tilstrekkelig til å fastslå at arbeidstaker stod til disposisjon, ville det strengt tatt ikke vært behov for å se nærmere på de konkrete forholdene. Domstolen forutsatte med andre ord at slik reisetid etter omstendighetene kan falle utenfor begrepet arbeidstid.

Fokuset på kjennetegnene ved hviletid i den konkrete vurderingen, kan samtidig sees som en bekreftelse av slik reisetid i utgangspunktet er arbeidstid. Utgangspunktet kan bare fravikes dersom de konkrete omstendighetene viser at reisetiden, på tross den er pålagt og nødvendig, kan fungere som effektiv hviletid.

Det tredje elementet $\mathrm{i}$ arbeidstidsbegrepet er at arbeidstakeren i løpet av denne tid må arbeide. Også her var vurderingen i det vesentlige basert på Tyco. ${ }^{37}$ EFTA-domstolen påpekte at arbeidstaker «fratas muligheten til å bestemme pendleavstand» når arbeidsgiver krever oppmøte på et annet sted enn det faste (avsnitt 79). Det var «derfor uvesentlig» hvor ofte slikt oppmøtested ble angitt, «med mindre virkningen er at arbeidstakerens arbeidssted flyttes til et nytt fast eller sedvanlig oppmøtested» (ibid). Her tok domstolen stilling til det tredje spørsmålet i foreleggelsen. Avklaringen er generell i formen, og begrunnelsen har uansett relevans for nødvendig reisetid i alle tilfeller der arbeidstaker pålegges arbeid på et annet oppmøtested enn et fast.

Manglende mulighet til å bestemme pendleavstand fremstår avgjørende ved vurderingen av det tredje elementet. Verken andre argumenter eller forholdene under reisen ble trukket inn. Domstolen sluttet direkte fra det at arbeidstakeren var «forpliktet til å påta seg» oppdrag et annet sted, til at reisen var en «integrert del» av arbeidet, og fastslo at arbeidstakeren som «en følge av dette» var «'i arbeid'» i direktivets forstand (avsnitt 80). I tillegg ble det poengtert klart og generelt at det er «uvesentlig» om reisen foregår utenfor alminnelig arbeidstid (ibid.). Også vurderingen av det tredje elementet har dermed relevans ut over de konkrete saksforholdene.

Et annet spørsmål er hva vurderingen av dette elementet tilfører, i lys av det foregående. Det kan virke uklart om det kreves noe i tillegg for å være «i arbeid», dersom arbeidstakeren er ansett å utføre sine arbeidsoppgaver eller plikter innenfor arbeidsforholdets ramme. (det første elementet). For som nevnt kreves verken aktivt arbeid eller en vurdering av intensitet. ${ }^{38}$ Argumentet om manglende mulighet til å bestemme pendleavstand er i prinsippet relevant for den $n \phi d v e n d i g e$ reisetid i alle tilfeller det er pålagt arbeid på et annet oppmøtested enn et fast. Argumentet er derfor knyttet til de samme forholdene som var avgjørende for det første 
elementet. Argumentet om pendleavstand får dermed preg av å være et støtteargument for det utgangspunktet domstolen først trakk opp.

Videre er det usikkert om «i arbeid» innebærer noe mer enn å stå til disposisjon (det andre elementet). En arbeidstaker kan tenkes å arbeide uten dermed å stå til disposisjon, for eksempel dersom man på eget initiativ utfører arbeidsoppgaver på et tidspunkt arbeidsgiver ikke forventer. Men siden aktivt arbeid ikke kreves, er det er vanskelig å forestille seg at en arbeidstaker som står til disposisjon, ikke dermed er «i arbeid». At reisen ble ansett som en integrert del av arbeidet (det tredje elementet), synes med andre ord å følge nærmest som konsekvens av at de to første elementene var tilstede.

Det er grunn til å knytte en kommentar til betydningen av aktivt arbeid. Selv om domstolen klart la til grunn at det ikke kreves aktivt arbeid eller en intensitetsvurdering, behøver det ikke nødvendigvis være helt irrelevant. I utgangspunktet kan en arbeidstaker som utfører arbeid utenfor alminnelig arbeidstid uten å være pålagt det av arbeidsgiver, for eksempel på en reise, anses for å beskjeftige seg med egne interesser. Vernehensyn kan likevel tale for at faktisk utført arbeid påvirker om tiden kan anses som effektiv hviletid. Grensen mellom det forventede og frivillige kan være vanskelig å trekke. Direktivet åpner heller ikke for at den enkelte arbeidstaker skal kunne velge å arbeide utover rammene, og unntaksadgangen er nærmere regulert selv for arbeidstakere som fastsetter sin egen arbeidstid. ${ }^{39}$ Man kan derfor ikke utelukke at utført arbeid i seg selv er et argument for at reisetid i det konkrete tilfellet anses som arbeidstid.

\subsection{Er EFTA-domstolens tolkning et brudd med EU/EØS-praksis?}

Det er viktig å ta stilling til hva slags rettsavklaring eller -utvikling EFTA-domstolens tolkning av arbeidstidsbegrepet representerer. I den grad tolkningen bygger på etablerte retningslinjer, vil den ha større vekt enn dersom den kan anses som et brudd med tidligere praksis.

EFTA-domstolen bygget, som nevnt, i hovedsak på premisser fra EU-domstolens avgjørelse i Tyco. Det var ikke opplagt at vurderingene der hadde overføringsverdi. I dommen fra lagmannsretten påpekte flertallet at Tyco gjaldt «en helt spesiell type arbeidstakere» og kunne «ikke se at denne dommen har særlig betydning for problemstillingen i vår sak». ${ }^{40}$ Det gir grunn til å se nærmere på forskjellene i saksforhold, EU-domstolens vurderinger i Tyco samt hvordan og hvorfor EFTA-domstolen benyttet premissene i Thue.

Politimannen hadde fast oppmøtested ved lensmannskontoret, mens arbeidstakerne i Tyco ikke hadde noe fast oppmøtested. Forskjellene i saksforholdene strakk seg lenger. Som forklart ovenfor hadde tvisten i Tyco sammenheng med arbeidsgivers omlegging av oppmøtested og arbeidstidsordning. Før omleggingen hadde arbeidstakerne fast oppmøtested 
på regionkontorene, og arbeidstiden inkluderte reisen mellom dette stedet og dagens første og siste kunde. Omleggingen til oppmøte ute hos kunde innebar altså at reisetid som hadde vært regnet som arbeidstid, ikke lenger ble det.

EU-domstolen la vekt på disse forholdene ved vurderingen av alle de tre begrepselementene i Tyco. Ved vurderingen av det første elementet tok domstolen utgangspunkt $i$ at reisetid til og fra første og siste kunde var regnet som arbeidstid før omleggingen. ${ }^{41}$ Arbeidsgiver ble ikke hørt med at arbeidstakerne først utførte sine arbeidsoppgaver og plikter når de var på plass ute hos kundene. Det ville åpne for en uthuling av beskyttelsen for slike arbeidstakere som reiser rundt til flere kunder i løpet av dagen, og skade formålet om å beskytte sikkerhet og helse. ${ }^{42}$ Transporten til kunder ble ansett som «en nødvendig forutsætning» for å utføre oppgavene. ${ }^{43}$ Generaladvokatens uttalelse knytter synspunktet til akkurat denne gruppen arbeidstakere:

«Arbejdstagerne i hovedsagen skal $n \phi d v e n d i g v i s ~ k \phi r e ~ r u n d t$ for at udføre deres opgaver med installation og vedligeholdelse af sikkerhedssystemer hos deres arbejdsgivers forskellige kunder. Med andre ord er disse arbejdstageres transport en nфdvendig forudsatning for, at de kan levere de tekniske ydelser til de af arbejdsgiveren anviste kunder. Denne transport skal således betragtes som en del af de pågældende arbejdstageres arbejde.» 44

I tillegg poengterte EU-domstolen at reisetiden mellom regionkontorene og kunder tidligere var regnet som en del av arbeidsoppgavene. Det illustrerte at reisetiden «var en del af disse arbeidstagernes opgaver og beskjæftigelse», reisenes karakter var ikke endret av omleggingenen. ${ }^{45}$

Vurdering av det første elementet var altså nært knyttet til de spesielle saksforholdene. EFTA-domstolen hadde imidlertid en klar og prinsipiell begrunnelse for å gi premisset anvendelse. Formåls- og systembetraktninger tilsa at vurderingene i Tyco ikke kunne begrenses til arbeidstakere uten et fast oppmøtested. Det ville «fordreie begrepet 'arbeidstid' og undergrave direktivets formål». ${ }^{46}$ Direktivet ville i så fall gi full beskyttelse for arbeidstakere uten fast oppmøtested og for arbeidstaker med fast arbeidssted for alle oppdrag, mens arbeidstakere i en «mellomposisjon» slik som politimannen, «ville bli nektet vern etter direktivet i situasjoner der de pålegges et annet oppmøtested enn sitt faste». ${ }^{47}$ Synspunktet var følgelig at direktivet må gi beskyttelse i alle situasjoner der reisetiden til og fra arbeidet varierer på grunn av ulike oppmøtesteder, enten dette skjer regelmessig eller tidvis.

Tyco avsnitt 30.

Tyco avsnitt 31 og 32.

Tyco avsnitt 32, som viser til generaladvokatens uttalelse, EU:C:2015:391, avsnitt 38.

Generaladvokatens uttalelse avsnitt 38 (kursivert her).

Tyco avsnitt 33.

Thue avsnitt 71.

Ibid. 
Ved vurderingen av det andre elementet, om arbeidstakeren sto til disposisjon, ble flere omstendigheter trukket inn. Men domstolen viste blant annet til den tidligere ordningen. Selv om arbeidstakerne hadde en viss frihet under reisene, hadde de hatt denne friheten tidligere mens reisene ble regnet som arbeidstid. Endringen av utgangspunktet for transporten ble ikke ansett å berøre «den retlige karakter» av arbeidstakernes forpliktelser. ${ }^{48}$

Ved vurderingen av det tredje elementet la EU-domstolen igjen betydelig vekt på at arbeidstakere ikke hadde fast oppmøtested og at reisetiden tidligere var ansett som arbeidstid. Domstolen anså arbeidstakere som «ikke langere har et fast arbejdssted» for å være «på arbejde» under reisen, og fortsatte:

«Eftersom transporterne er en uadskillelig del af at være en arbejdstager, som ikke har et fast eller sadvanligt arbejdssted - således som generadvokaten har anført i punkt 48 i forslaget til afgærelse - kan sådanne arbejdstageres arbejdssted nemlig ikke indskrænkes til disse arbejdstageres fysiske arbejdssted hos deres arbejdsgivers kunder.» 49

EU-domstolen poengterte at det var arbeidsgivers beslutning å nedlegge regionkontorene, og trakk så frem argumentet om manglende mulighet til å bestemme pendleavstand:

«Da arbejdstagerne har mistet muligheden for frit at bestemme afstanden mellem deres bopæl og det sædvanlige sted for deres arbejdsdags begyndelse og afslutning, kan de ikke være forpligtet til at påtage sig ansvaret for deres arbejdsgivers valg vedrørende nedlæggelsen af disse kontorer» (avsnitt 44).

Argumentet om pendleavstand i Tyco var altså knyttet til avstanden til det vanlige arbeidstedet, og arbeidsgivers valg om å endre oppmøtested og arbeidstidsordning. EFTAdomstolen vektla argumentet på tross av at reisetiden i saken verken gjaldt reise til det vanlige arbeidsstedet eller en omlegging av arbeidsordningen. Det kan hevdes at pendleargumentet har mindre gjennomslag når oppmøtestedet bare tidvis varierer enn når det varierer regelmessig. EFTA-domstolen ga ingen nærmere begrunnelse for bruken, og argumentet kan derfor fremstå svakt fundert. En slik kritikk har uansett begrenset betydning. Som forklart ovenfor ble det benyttet som et støtteargument, og det er i tråd med praksis tolke dette elementet så vidt at det har liten selvstendig betydning.

Denne bruken av premisser fra Tyco viser etter mitt syn at EFTA-domstolen utvikler tolkningen av arbeidstidsbegrepet, i tråd med og ikke på tvers av, EU-domstolens føringer.

EFTA-domstolen viste også til annen praksis. Presiseringen av hva som utgjør effektiv hviletid, viste til domstolens egne vurderinger i Matja Kumba:

«Det er bare når arbeidstakerne kan forlate arbeidsmiljøet i hvileperiodene og fritt og uavbrutt beskjeftige seg med egne interesser, at hvileperiodene kan anses effektive og ikke utgjøre 'arbeidstid' (se Matja Kumba, som omtalt over, avsnitt 41 og rettspraksis som det vises til der.)» 50

48 Tyco avsnitt 39.

Tyco avsnitt 43 (kursivert her). Generaladvokaten la i avsnitt 48 til grunn at arbeidsplassen for slike arbeidstakere ikke kan «reduceres til teknikernes fysiske tilstedeværelse hos kunderne». 
Formuleringen er imidlertid både strengere og mer vidtrekkende enn i Matja Kumba. Der ble frihet til å forlate «arbeidsstedet» fremstilt som noe som «kan» gjøre hvileperioden effektiv, mens domstolen her anser frihet til å forlate «arbeidsmiljøet» som en nødvendig betingelse for å være hviletid, jf. «[d] et er bare når ...». ${ }^{51}$ Den strengere formuleringen har støtte i annen praksis fra EU-domstolen, som antydet i sitatet. I Jaeger ble det lagt til grunn at arbeidstakeren må ha mulighet til å være «væk fra sit arbejde» for å hvile seg effektivt, og «den afgørende begrundelse» for at en leges vakttjeneste var arbeidstid, var plikten til fysisk tilstedeværelse på arbeidsstedet. ${ }^{52}$ Men at argumentet har samme vekt når det gjelder frihet til å forlate «arbeidsmiljøet» under en reise, er ikke like opplagt. EU-domstolen har riktignok uttalt at arbeidsstedet ikke kan redusers til «det fysiske arbejdssted», men det gjaldt arbeidstakere uten fast arbeidssted. ${ }^{53}$ EFTA-domstolen yter derfor et selvstendig bidrag til tolkningen når dette trekkes inn under den strenge formuleringen. På den annen side er det ikke dermed sagt at det er avgjørende for vurderingen av reisetid at man kan forlate transportmiddelet eller fritt avvike fra reiseruten. Som tidligere påpekt, forutsatte domstolen at «en viss fleksibilitet» kunne få betydning. Og spørsmålet kom heller ikke på spissen ettersom politimannen var underlagt såpass mange andre begrensninger under reisene.

Samlet sett er det nokså klart at EFTA-domstolen utvikler tolkningen av arbeidstidsbegrepet. Men etter min vurdering er det ingen klare brudd med tidligere praksis.

\section{$5 \quad$ Retningslinjene for tolkningen - en utvidelse av arbeidstidsbegrepet?}

Drøftelsen har vist at EFTA-domstolens tolkning av arbeidstidsbegrepet er lagt til grunn av Høyesterett i Reisetid, gir grunnlag for generelle retningslinjer for vurderingen av når reisetid er arbeidstid og ikke kan kritiseres for å bryte med EU/EØS-rettslig praksis. Retningslinjene kan sammenfattes slik:

- Der arbeidstaker pålegges arbeid på et annet sted enn et fast oppmøtested, vil $n \phi d v e n d i g$ reisetid som et utgangspunktet anses som arbeidstid, selv om den ligger utenfor den alminnelige arbeidstiden.

- Reisetiden regnes likevel ikke som arbeidstid dersom arbeidstakeren etter en konkret vurdering står så fritt under reisen at tiden er effektiv hviletid.

- Hvorvidt tiden er effektiv hviletid, beror på en konkret vurdering av arbeidstakerens mulighet til fritt og uavbrutt å beskjeftige seg med egne interesser.

- I den konkrete vurderingen må ulike typer av begrensninger i friheten tas i betraktning. En vurdering av mengden eller intensiteten i utført arbeid er ikke påkrevet, men kan være relevant. EU:C:2010:612, avsnitt 50 og 51. Disse er nevnt i Matja Kumba avsnitt 41. 
- Hvor ofte pålegg om annet oppmøtested gis, er uvesentlig med mindre det faste arbeidsstedet endres. I så fall er utgangspunktet om at reisetid til og fra det faste arbeidsstedet ikke er arbeidstid, igjen relevant.

Retningslinjene representerer etter min oppfatning en utvikling - og en utvidelse - av arbeidstidsbegrepet i norsk kontekst.

For det første kan man neppe opprettholde et alminnelig utgangspunkt om at reise utenfor alminnelig arbeidstid, til og fra det stedet arbeidet skal utføres, ikke er arbeidstid.

Utgangspunktet gjelder fremdeles for reise til og fra et fast oppmøtested. Men det kan ikke opprettholdes for reiser til og fra andre oppmøtesteder enn et fast, enten det varierer regelmessig eller bare tidvis. For $n \phi d v e n d i g$ reisetid til pålagt arbeid på annet oppmøtested, er utgangspunktet nå heller motsatt.

Det er heller ikke helt treffende å hevde at arbeidstidsbegrepet ikke er endret fordi spørsmålet om reisetid er arbeidstid, fremdeles beror på en konkret vurdering. Vurderingen er ikke «bare» konkret, den er strukturert. Dels er det tre begrepselementer som skal vurderes, dels er det lagt flere viktige føringer for vurderingen av det enkelte element. Den konkrete vurderingen som kan avgjøre grensedragningen i det enkelte tilfellet, er heller ikke helt den samme som før. Om tiden er effektiv hviletid har fătt en mer sentral plass enn det har hatt i norsk tradisjon. Effekten av dette synes å være en utvidelse av arbeidstidsbegrepet.

Dreiningen i vurderingstema kan illustreres ved hjelp av Rt. 2001 s. 418 Kårst $\not$. Saken gjaldt arbeidstakere ved Statoils anlegg på Kårstø og reiste spørsmål om reise- og gangtid fra hovedporten til arbeidsstedene inne på anlegget var arbeidstid i arbeidsmiljølovens forstand. ${ }^{54}$ Høyesterett avviste at kjennetegn ved arbeidstidsbegrepets motsats kunne ha verdi ved vurderingen av om arbeidstakerne stod «til disposisjon»: «Fritid er negativt bestemt i loven og gir etter min mening ikke noe selvstendig bidrag til tolkningen av uttrykket arbeidstid» (s. 425). Det står i klar kontrast til EU- og EFTA-domstolenes fokus på begrepet 'hviletid'. Høyesterett poengterte videre at det «ikke nфdvendigvis må utføres arbeid» (ibid., kursivert her). Men den konkrete vurderingen tyder likevel på at utførelse av arbeidsoppgaver stod mer sentralt enn om tiden kunne fungere som hviletid. Arbeidstakerne var underlagt betydelige restriksjoner fra passering av hovedporten. ${ }^{55}$ Det var ikke tilstrekkelig til at arbeidstakerne ble ansett å stå til disposisjon. Førstvoterende fant det nemlig «klart at det ikke utføres arbeid selv om arbeidsgiver har pålagt arbeidstakerne restriksjoner under transporten av hensyn til sikkerheten» (s. 426, kursivert her).

54 Saken reiste ikke spørsmål om brudd på vernereglene. Det sentrale spørsmålet var om arbeidsavtalene var til hinder for at arbeidsgiver i kraft av styringsretten kunne fastsette nye oppmøtesteder med virkning for beregningen av arbeidstid. Tolkningen av lovens arbeidstidsbegrep kom inn ved tolkningen av arbeidsavtalene fordi de ble ansett å bygge på samme begrep.

55 Det gjaldt generelle restriksjoner, blant annet overvåkning, forbud mot bruk av egen bil, røyking og bruk av mobiltelefon samt pålegg om vernetøy. For arbeidstakerne gjaldt i tillegg blant annet en rapporteringsplikt knyttet til hms-krav. 
På denne bakgrunn kan det reises spørsmål om vurderingen i Kårst $\varnothing$ ville kunne opprettholdes i dag. I Reisetid erkjente Høyesterett at det i Kårst $\phi$ var stilt «strenge krav», men viste til at saken gjaldt reiser til og fra det faste oppmøtestedet, som «i utgangspunktet faller utenfor begrepet 'arbeidstid'». ${ }^{56}$ Også EFTA-domstolen la til grunn at endring av fast oppmøtested kan betraktes på annen måte. ${ }^{57}$ Likevel kan det settes spørsmålstegn ved vurderingen. Tvisten gjaldt ikke hele reisen, kun tiden fra passering av hovedporten og frem til oppmøtestedet. I denne tiden gjaldt omfattende restriksjoner som arbeidstakere normalt ikke er underlagt. Tvisten var utløst av en omlegging av oppmøtested som forlenget daglig reisetid med ca. 20 til 25 minutter. Realiteten for flere av arbeidstakerne var at reisetid som tidligere hadde vært regnet som arbeidstid, ikke lenger ble det. ${ }^{58}$ Det gir en viss parallell til Tyco, og der den tidligere ordningen ble betraktet som en indikasjon på at reisetiden var arbeidstid. Det hersker derfor en viss tvil ved om Høyesteretts vurdering er i tråd med dagens tolkning av begrepet.

\section{Utfordringer på veien videre}

Reisetid etterlater både uløste spørsmål og andre utfordringer. Dette fors $\varnothing$ ket på en analyse berører bare enkelte av dem.

Én utfordring er behovet for ytterligere avklaring av arbeidstidsbegrepets innhold etter direktivet og lovens parallelle vernebestemmelser. Et viktig spørsmål er hva som mer konkret skal til for å fravike utgangspunktet om at nødvendig reisetid til pålagt arbeid på annet oppmøtested enn et fast, er arbeidstid. Når står arbeidstaker tilstrekkelig fritt til at slik reisetid er effektiv hviletid? Er det tilstrekkelig om arbeidsgiver klargjør at man verken trenger å utføre arbeid eller være tilgjengelig? Kreves det i tillegg et transportmiddel med gode hvilemuligheter eller anledning til å velge et slikt? Faller det utenfor arbeidsbegrepet dersom arbeidstakeren kan påvirke hvor og når reiser skal gjennomføres?

Dersom det ikke er praktisk mulig å organisere pålagte og nødvendige reiser på en måte som klart tilfredsstiller kravene til hviletid, vil det skape betydelig vanskeligheter. For eksempel vil det å sende arbeidstakere på en lengre flyreise i seg selv kunne være et brudd på hviletidsbestemmelsene. Praktiske og samfunnsøkonomiske hensyn taler derfor med styrke for at reiser organisert som antydet ovenfor, faller utenfor arbeidstidsbegrepet. Men det er foreløpig uavklart hvilke nærmere krav som kan stilles.

En annen utfordring handler om forholdet mellom dette arbeidstidsbegrepet og begrepsinnholdet etter andre lovbestemmelser. Reisetid tar kun stilling til begrepsinnholdet etter de bestemmelsene i aml. kap. 10 som gjennomfører direktivet. Selv om ordlyden i aml. §

58 Dagtidsansatte møtte ved hovedport før endringen. Skiftansatte hadde møtt ute på anlegget, men også for dem førte endringen til at visse reisedistanser som tidligere hadde vært arbeidstid, ikke lenger var det.
} 
10-1 (1) indikerer en definisjon med virkning for hele loven, kan avgrensningen altså variere både innad i loven og innenfor kap. 10. Det er ikke så særegent som det kan virke. Også andre arbeidsrettslige grunnbegreper har en felles kjerne eller består av visse elementer, samtidig som grensedragningene varierer med rettsvirkningene. ${ }^{59}$ Det er heller ikke særegent at EU/EØS-retten legger press på en tradisjonell begrepsforståelse. ${ }^{60}$ Åpningen for nyanser er like fullt en utfordring for tolkningen. Hvilken betydning har tolkningen for andre regler med et begrep om 'arbeidstid'? Det gjelder blant annet reglene om overtidstillegg og søndagsarbeid, ${ }^{61}$ deltidsansattes rett til arbeidstid svarende til faktisk arbeidstid ${ }^{62}$ og yrkesskadeforsikring. ${ }^{63}$ Det kan være holdepunkter for et snevrere begrep, som krav om aktivt arbeid. Gode grunner kan samtidig tale for tolkning i tråd med vernebestemmelsene. Det er et opplagt behov for en gjennomgang og klargjøring fra lovgiverhold, om hvilke bestemmelser som skal tolkes i tråd med arbeidstidsdirektivet og hvilke som skal forstås annerledes.

Den tredje og vanskeligste utfordringen gjelder forholdet mellom lov og tariffregulering. Det klare skillet i Reisetid i tolkningen av lov og tariffavtale kan virke tilforlatelig. Det er flere eksempler på at tariffregulering av arbeidstid er tolket selvstendig. ${ }^{64}$ I prinsippet kan det skilles mellom regulering av arbeidstidens lengde (der vernebestemmelsene setter rammer som kan fravikes etter nærmere regler) og godtgjørelsen (som i utgangspunktet ikke er lovregulert).

Men skillet var nok ikke var like klart før. Da 'arbeidstid' ble definert i aml. 1977, var tariffavtaler forutsatt å kunne påvirke avgrensingen, blant annet for reisetid. ${ }^{65}$ I forarbeidene er det gitt retningslinjer for når reisetid er arbeidstid, og tilføyd: «Det vil ofte følge av tariffavtaler e. 1. hvor grensen går i slike tilfelle». ${ }^{66}$ Direktivet innrømmer ingen fleksibilitet for tariffpartene ved begrepsavgrensningen, deres frihet er i stedet avgrenset til godtgjørelsen og ellers «rammet inn» av unntakshjemler. Kombinert med den vide tolkningen av direktivets begrep har det antakelig skapt sterkere spenninger i begrepsforståelsen etter lov og tariffavtale. Det er trolig mange arbeidsgiverorganisasjoner som i disse dager leter i arkivene

59 Se om begrepene 'arbeidsgiver' i Marianne Jenum Hotvedt, Arbeidsgiverbegrepet, Oslo 2016 og 'arbeidstaker' i Marianne Jenum Hotvedt, «Arbeidstaker - quo vadis?», Tidsskrift for Rettsvitenskap, 2018 s. $42-103$.

Ibid.

61 LB-2013-88645 bygger på at innslagspunktet for overtidstillegg beror på nasjonal rett, ikke på direktivet. Reglene om søndagsarbeid har ikke bakgrunn i direktivet og er først og fremst begrunnet i sosiale og velferdsmessige hensyn, se NOU 2004: 5 s. 263.

Aml. § 14-4 a og § 14-4 b.

63 Etter lov 16. juni nr. 65 om yrkesskadeforsikring $\S 10$ skal forsikringen dekke skade eller sykdom «som arbeidstakere påføres i arbeid på arbeidsstedet i arbeidstiden».

Se bla. ARD 1988 s. 72.

65 Arbeidstidskapitlet ble utformet i tett samarbeid med partene. Planen om at bestemmelsene skulle utformes av en partssammensatt arbeidsgruppe, ble forlatt fordi LO og N.A.F ønsket å forhandle frem en felles løsning. Da det ikke lyktes, ble bestemmelsene utformet på bakgrunn av forslag fra LO, supplert med uttalelser fra blant annet N.A.F., se Ot.prp. nr. 41 (1975-1976) s. 35.

Ibid. s. 62. 
etter holdepunkter i tariffhistorien for et snevrere arbeidstidsbegrep enn det loven nå bygger på.

Et annet problem er partene har ikke nødvendigvis har hatt et bevisst forhold til om tariffreguleringen bygger på et annet arbeidstidsbegrep enn lovens. Reisetid illustrer det. Anførselen om at tariffavtalens arbeidstidsbegrep skilte seg fra lovens, kom opp sent i saksgangen. ${ }^{67}$ Lovgiver kan i samråd med partene i arbeidslivet vurdere om direktivets unntakshjemler er benyttet på hensiktsmessig måte. Men det vil uansett ikke kunne gi avklaring for regulering av godtgjørelse.

At tariffreguleringen av arbeidstidens lengde og godtgjørelsen gjerne henger sammen, kan skape ytterligere problemer. Usikkerhet om reglene om godtgjørelse bygger på lovens arbeidstidsbegrep eller ikke, har store praktiske og økonomiske implikasjoner. Det har sprengkraft til å utløse en rekke retts- og interessetvister. Siden regulering av arbeidstid og godtgjørelse har stor samfunnsøkonomisk betydning, bør det oppta flere enn partene. Slike spørsmålene må likevel først og fremst finne sin løsning mellom partene, i rettssystemet og ved tariffoppgjør. 